\title{
Use of factorial experimental design to evaluate how biotic and abiotic factors influence cadmium accumulation in the unicellular alga Dunaliella bioculata
}

\author{
Edith Heuillet $^{1}$, Alain Bermond ${ }^{2}$, Nicole Jeanne ${ }^{1}$, Simone Puiseux-Dao ${ }^{1}$, Christian \\ Ducauze $^{2}$
}

${ }^{1}$ Laboratoire de Cytophysiologie Végétale et Toxicologie Cellulaire, U.A. C.N.R.S. 567, Université Paris VII, couloir 53-54, 3ème étage, 2 place Jussieu, F-75251 Paris Cedex 05, France

${ }^{2}$ Laboratoire de Chimie Analytique, Institut National Agronomique Paris-Grignon, 16 rue Claude Bernard, F-75005 Paris, France

\begin{abstract}
Using Dunaliella bioculata, a marine unicellular alga, as a model, the influence of biotic and abiotic variables on the bioaccumulation of cadmium was evaluated. Factorial experimental design and response-surface methodology were used to follow the variation of cadmium uptake caused by variations of the following variables: (a) cadmium concentration in the medium, (b) calcium concentration of culture medium, (c) duration of exposure during the period of light, (d) period of darkness, (e) the exponential phase and $(f)$ the stationary phase of the growth. This methodology proved to be very efficient, for only 8 experiments were necessary to follow the cadmium uptake for each condition. We thus showed that cadmium uptake increases with cadmium concentration in the medium and with exposure time, but that their effects are not simply additive. Cadmium uptake depends heavily on the calcium concentration in the medium. Different hypotheses for the cadmiun dosorption mechanism and for the physiological explanation of the Cd-Ca antagonism are discussed.
\end{abstract}

\section{INTRODUCTION}

The increasing occurrence of heavy metals (cadmium included) through the disposal of complex effluents has stimulated many studies on both the toxicity to aquatic biota (Overnell 1975, Sylverberg 1976 , de Filippis et al. 1981, Jenkins et al. 1983, SantiagoFandino 1983) and the uptake of these elements by aquatic biota (Flateau \& Gauthier 1983, Fisher et al. 1984, Mac Leese \& Ray 1984, Ravera 1984, Ray 1984), particularly by phytoplankton. Studies on the accumulation of heavy metals by these cells in culture showed that uptake depends on many different variables such as exposure time (Gnassia-Barelli \& Hardstedt-Roméo 1982), other heavy metals (Gray 1974, Stary \& Kratzer 1982), natural exudates (Hardstedt-Roméo \& GnassiaBarelli 1980), nutrient cations such as $\mathrm{Ca}^{2+}, \mathrm{Mn}^{2+}, \mathrm{Fe}^{3+}$ $\mathrm{Zn}^{2+}, \mathrm{Mg}^{2+}$ (Braek et al. 1980, Singh \& Pandey 1981), salinity (Rebhun \& Ben-Amotz 1986) and growth phase (Gipps \& Coller 1982). However, in these toxicological studies, the variables were tested individually. The purpose of the present work was to investigate simultaneously the influence of different variables on cadmium uptake and to detect possible interactions. For this, we used an experimental factorial design at 2 levels and a response surface methodology; these had been successfully applied by Dumenil et al. (1975) Mathews (1981) and Sanderson et al. (1984).

The biological material chosen was the wall-less alga Dunaliella bioculata. Having taken into account both the preceding X-ray microanalytical study of cadmium distribution in Dunaliella bioculata (Heuillet et al 1986) and physiological data concerning this alga (Marano 1980, Grizeau et al. 1982, Jeanne 1982), we decided to study the following variables: light or dark period, exponential or stationary phase of growth, cadmium concentration, duration of contamination and calcium content of the medium. This last variable was chosen as $\mathrm{Ca}^{2+}$ plays an essential role in many key biological processes and is considered an antagonist to 
cadmium (Fuhrer 1983, Plishker 1984). Moreover, the growth of this euryhaline alga is largely independent of the calcium concentration of the medium.

\section{MATERIALS AND METHODS}

Culture conditions and biomass determination. Dunaliella biocuiata was cultivated axenically in an artificial seawater medium (Table 1 ) at constant temperature, $22 \pm 1{ }^{\circ} \mathrm{C}$. Cultures were exposed to a light

Table 1. Composition of the artificial seawater medium (Grizeau 1982)

\begin{tabular}{|ll|}
\hline $\mathrm{NaCl}$ & $0.5 \mathrm{M}$ \\
$\mathrm{MgSO}_{4} \cdot 7 \mathrm{H}_{2} \mathrm{O}$ & $4 \times 10^{-2} \mathrm{M}$ \\
$\mathrm{NaNO}_{3}$ & $1 \times 10^{-2} \mathrm{M}$ \\
$\mathrm{CaCl}_{2}$ & $1 \times 10^{-2} \mathrm{M}$ \\
$\mathrm{K}_{2} \mathrm{HPO}_{4}$ & $1 \times 10^{-4} \mathrm{M}$ \\
$\mathrm{Tris}^{-} \mathrm{HCl}_{1} \mathrm{pH} 7.2$ & $2 \times 10^{-2} \mathrm{M}$ \\
$\mathrm{MnCl}_{2} \cdot 4 \mathrm{H}_{2} \mathrm{O}$ & $7 \times 10^{-6} \mathrm{M}$ \\
$\mathrm{ZnCl}_{2}$ & $1 \times 10^{-6} \mathrm{M}$ \\
$\mathrm{CoCl}_{2} \cdot 6 \mathrm{H}_{2} \mathrm{O}$ & $2 \times 10^{-8} \mathrm{M}$ \\
$\mathrm{FeCl}_{3}$ & $2 \times 10^{-6} \mathrm{M}$ \\
$\mathrm{Na}_{2} \mathrm{EDTA} 2 \mathrm{H}_{2} \mathrm{O}$ & $3 \times 10^{-6} \mathrm{M}$ \\
\hline
\end{tabular}

intensity of $50 \mathrm{~W} \mathrm{~m}^{-2}$ and to light/dark cycles of $12 \mathrm{~h}$. Under these conditions, divisions occur during the first part of the dark period. The stock cultures were cultivated in gently stirred 41 round-bottomed flasks.

The biomass was monitored by counting the cells with a Coulter Counter (Coultronics Model ZF) equipped with a cylindrical micro-orifice (diameter 100 $\mu \mathrm{m})$. The counting precision is $1 \%$.

Statistical and experimental methodology. To study the influence of variables (cadmium and calcium concentration in the medium, duration of exposure, light or dark period, growth phase) on the cadmium uptake by algae, an experimental factorial design and response surface methodology were used. This methodology consists of an empirical modeling technique designed to evaluate the relations between a group of controlled experimental variables and the observed results for one or more selected criteria.

A priori knowledge of the studied process is thus necessary to achieve a descriptive model. A polynomial model with dual interactions was used because interactions higher than first order are very improbable (Cheynier et al. 1983).

$$
Y=b_{\bigcirc}+\Sigma_{\mathrm{i}} b_{i} X_{1}+\Sigma_{\mathrm{i}} \Sigma_{\mathrm{j}} b_{\mathrm{l}} X_{\mathrm{k}} X_{\mathrm{j}}+e
$$

where $Y=$ the observed response: $b_{O}=$ the grand average response; $b_{1}, b_{\mathrm{ij}}=$ the measures of the effects (or coefficients); $X_{\mathrm{i}}=$ the explanatory variable; $X_{\mathrm{i}} X_{\mathrm{j}}$ characterizes the interaction between $X_{1}$ and $X_{\mathrm{j}}$ (also called transformed variable); $e=$ the residue or error estimation.

The second step of this methodology is to choose an experimental design. Several designs for studying such a model have been described. We selected the complete factorial design at 2 levels proposed by Box et al. (1978). Thus, 8 experiments $\left(2^{3}\right)$ were necessary for the estimation of the 7 coefficients of the model (Table 2):

$$
\begin{gathered}
Y=b_{\mathrm{O}}+b_{1} \cdot[\mathrm{Cd}]+b_{2} \cdot[\mathrm{Ca}]+b_{3} \cdot D+b_{12} \cdot[\mathrm{Cd}] \cdot[\mathrm{Ca}]+ \\
b_{13} \cdot[\mathrm{Cd}] \cdot D+b_{23} \cdot[\mathrm{Ca}] \cdot D
\end{gathered}
$$

where $[\mathrm{Cd}]=$ cadmium concentration in the medium; $[\mathrm{Ca}]=$ calcium concentration of the culture medium; $D$ $=$ duration of exposure.

Table 2. Complete factorial design consisting of 8 experiments for the study of 3 experimental variables in coded units. For explanation of + and - , see Table 3

\begin{tabular}{|cccc|}
\hline Run no. & {$[\mathrm{Cd}]$} & {$[\mathrm{Ca}]$} & $\begin{array}{c}\text { Duration of } \\
\text { contamination }\end{array}$ \\
\hline 1 & - & - & - \\
2 & + & - & - \\
3 & - & + & - \\
4 & + & + & - \\
5 & - & - & + \\
6 & + & - & + \\
7 & - & + & + \\
8 & + & + & + \\
\hline
\end{tabular}

For each condition (light, dark, exponential phase, stationary phase) the factorial design was repeated twice to give error variance between replicates. In fact the adequacy of the model can be checked using several criteria: the coefficient of determination $R^{2}$, Fisher's F-test, and analysis of the residuals. The significance of variables can be evaluated by Student's t-tests.

The third step of this methodology is to define the limits of the experimental domain to be explored. These limits are set as widely as possible to obtain a clear response from the model. The boundaries of the experimental domain correspond to 2 levels of varia-

\begin{tabular}{|c|c|c|c|}
\hline \multirow[b]{2}{*}{$\begin{array}{l}\text { Code } \\
\text { units }\end{array}$} & \multicolumn{3}{|c|}{ Experimental variables } \\
\hline & $\begin{array}{c}{[\mathrm{Cd}]} \\
\left(\mu \mathrm{g}\left[^{-1}\right)\right.\end{array}$ & $\begin{array}{c}{[\mathrm{Ca}]} \\
(\mathrm{mM})\end{array}$ & $\begin{array}{l}\text { Duration of } \\
\text { contamination } \\
\qquad(\mathrm{h})\end{array}$ \\
\hline- & 10 & 1 & 1 \\
\hline+ & 1000 & 10 & 12 \\
\hline
\end{tabular}
bles studied (Table 3).

Table 3. Variable levels in coded and natural units 
The values attributed to each level were chosen as a function of the following criteria: the values should be significantly different in order to have a significant response; the concentrations of calcium and cadmium should not modify the growth of algal population; the duration of the period of contamination in the light or in the dark period should be in accordance with the photoperiod.

For uptake experiments, $400 \mathrm{ml}$ of the stock culture were distributed into sterilized $1 \mathrm{l}$ Erlenmeyer flasks. For the exponential phase experiments, the cell density was $1.2 \times 10^{6} \pm 0.2 \times 10^{6}$ cells $\mathrm{ml}^{-1}$. For the stationary phase experiments, the cell density reached $1.5 \times 10^{6}$ $\pm 0.2 \times 10^{6}$ cells $\mathrm{ml}^{-1}$. Depending on the runs, $\mathrm{CdCl}_{2}$ (Titrisol Merck) was added axenically at final concentrations of 10 or $1000 \mu g l^{-1}$ over 1 or $12 \mathrm{~h}$, in light or dark, according to the design. For studies carried out in the dark, cultures were transferred to a dark room at $22{ }^{\circ} \mathrm{C}$.

At the end of the experiments, the cells were counted and the cultures were filtered using $1.2 \mu \mathrm{m}$ 'Sartorius' membrane filters. The cells were then collected along with the filters and dried at $80^{\circ} \mathrm{C}$ for $24 \mathrm{~h}$ before metal analysis.

Metal analysis. All the glassware used was precleaned with diluted $\mathrm{HNO}_{3}(1 / 3)$ and rinsed with deionized water (Millipore apparatus).

The metal analysis consisted of a wet-way mineralization of the biological samples, followed by measurement of the metal concentration by furnace atomic absorption spectrometry (Varian AA 147.5. gas Argon, background corrector). Since the objective of this work was based on comparison of quantitative data, optimization of the analytical methods was an important step. Thus, we had to optimize the conditions of mineralization and the ashing and atomization temperatures. To assure its efficacy, it was also necessary to consider these principal operational parameters simultaneously and not just one factor at a time. This work was carried out following the methodology of Doelhert's network derived from the simplex method (Doehlert 1970, Feinberg \& Wirth 1984). This methodology has been shown to be an efficient and rapid means for optimizing operational conditions in analytical chemistry. Thus, the cells were digested with $4 \mathrm{ml}$ of 'Merck Suprapur' nitric acid and $6 \mathrm{ml}$ of deionized water at $85^{\circ} \mathrm{C}$ for $6 \mathrm{~h}$. The ashing and atomization temperatures were $200^{\circ} \mathrm{C}$ and $1700^{\circ} \mathrm{C}$, respectively.

The quantity of cadmium in each sample was measured according to the method of standard additions. Metal concentration values were corrected for metal retention using blank filters, through which contaminated medium without cells had been passed. The variation coefficient of results was $15 \%$.

The high concentration of salts in the medium did not permit verification of cadmium contamination in the medium by the same analytical technique. However it was easy to verify the cadmium levels in the culture medium by differential pulse anodic stripping voltametry (Bard \& Faulkner 1980).

\section{RESULTS}

The results are expressed in ng of cadmium per $10^{6}$ cells, since measuring cell weights is difficult (the salts of the medium were retained on the filters with the cells).

The light, dark, exponential or stationary phase variables were studied in separate experiments. Thus, 4 experimental designs were used with 3 variables ([Cd], [Ca], duration of exposure). Results are presented in Table 4

Each of the observed values was compared with the predicted values calculated from the significant coefficients of the models in Tables 5 and 6 .

The determination coefficient and Fisher's F-test demonstrated a high significance for the regression model. The comparison of residuals calculated from Table 4 with the residual variance indicated that no residual exceeds twice the square root of the residual variance. All of these considerations indicated a good adequacy of the polynomial model proposed to explain the accumulation of cadmium observed. However, in the stationary phase and in the light, for [Cd] $=10 \mu \mathrm{g}$ $1^{-1},[$ Ca $]=10 \mathrm{~m} M \hat{i}$ and duration $=12 \mathrm{~h}$, the response was 15.5 where 0 was predicted. This value was abnormally high and exterior contamination could have occurred.

From Table 4, the following conclusions could be reached. (1) Cadmium was taken up by Dunaliella bioculata whatever the conditions $\left(10\right.$ or $1000 \mu \mathrm{g} \mathrm{Cd}^{-1}$ 1 or $10 \mathrm{mM} \mathrm{Ca}$; 1 or $12 \mathrm{~h}$; light or dark condition; exponential or stationary phase). (2) However, the cadmium accumulation differed quantitatively as a function of the studied variables. For example, when the algae in the exponential phase were cultivated during $12 \mathrm{~h}$ light in a medium containing $10 \mathrm{mMCa}$, the rate of cadmium accumulation was 34 -fold higher in the culture contaminated with $1000 \mu \mathrm{g} \mathrm{Cd} \mathrm{l^{-1 }}$ than in

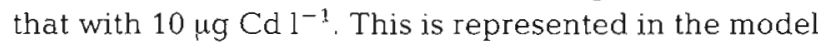
$Y_{\mathrm{A}}$ by the positive coefficient of the [Cd] variable. In the same way, the rate of cadmium accumulation may increase with the duration of contamination. This is noted in the models $Y_{\mathrm{A}}$ and $Y_{\mathrm{D}}$ by the positive coefficient of this variable. On the other hand, when the algae in the stationary phase were cultivated during $12 \mathrm{~h}$ light in a medium contaminated with $1000 \mu \mathrm{g} \mathrm{Cd} \mathrm{l}^{-1}$, the rate of cadmium accumulation was 2.8-fold lower in the culture containing $10 \mathrm{mM} \mathrm{Ca}$ than in that containing 
Table 4. Observed responses and predicted values calculated from the significance coefficients of the models in Tables 5 and 6

\begin{tabular}{|c|c|c|c|c|c|c|c|c|}
\hline & \multirow[t]{2}{*}[\mathrm{Ca}]{$(\mathrm{mM})$} & \multirow[t]{2}{*}{$D(\mathrm{~h})$} & \multicolumn{3}{|c|}{$10 \mu \mathrm{g} \mathrm{Cd} 1^{-1}$} & \multicolumn{3}{|c|}{$1000 \mu \mathrm{g} \mathrm{Cd} 1^{-1}$} \\
\hline & & & Run no. & $\begin{array}{l}\text { Observed } \\
\text { responses }\end{array}$ & $\begin{array}{c}\text { Predicted } \\
\text { values }\end{array}$ & Run no. & $\begin{array}{l}\text { Observed } \\
\text { responses }\end{array}$ & $\begin{array}{c}\text { Predicted } \\
\text { values }\end{array}$ \\
\hline \multicolumn{9}{|c|}{ Exponential phase } \\
\hline \multirow[t]{4}{*}{ Light } & 1 & 1 & 1 & 0.53 & 0.3 & 2 & 3.78 & 3.3 \\
\hline & & 12 & 5 & 0.43 & 0.5 & 6 & 19.31 & 17.1 \\
\hline & 10 & 1 & 3 & 0.27 & 0.3 & 4 & 2.71 & 3.3 \\
\hline & & 12 & 7 & 0.57 & 0.5 & 8 & 14.86 & 17.1 \\
\hline \multirow[t]{4}{*}{ Dark } & 1 & 1 & 1 & 1.21 & 0.5 & 2 & 10.32 & 14.3 \\
\hline & & 12 & 5 & 1.32 & 2.1 & 6 & 16.92 & 15.9 \\
\hline & 10 & 1 & 3 & 0.60 & 0.3 & 4 & 10.75 & 12.1 \\
\hline & & 12 & 7 & 1.26 & 2.3 & 8 & 9.37 & 10.5 \\
\hline \multicolumn{9}{|c|}{ Stationary phase } \\
\hline \multirow[t]{4}{*}{ Light } & 1 & 1 & 1 & 0.46 & -1.4 & 2 & 19.12 & 21.0 \\
\hline & & 12 & 5 & 0.36 & 2.4 & 6 & 26.48 & 24.8 \\
\hline & 10 & 1 & 3 & 0.44 & 2.2 & 4 & 14.35 & 12.6 \\
\hline & & 12 & 7 & 15.50 & -1.6 & 8 & 7.04 & 8.8 \\
\hline \multirow[t]{4}{*}{ Dark } & 1 & 1 & 1 & 1.93 & 1.7 & 2 & 9.92 & 9.9 \\
\hline & & 12 & 5 & 0.73 & 0.9 & 6 & 22.00 & 21.9 \\
\hline & 10 & 1 & 3 & 1.38 & 1.5 & 4 & 5.82 & 5.7 \\
\hline & & 12 & 7 & 0.73 & 0.7 & 8 & 17.74 & 17.7 \\
\hline
\end{tabular}

Table 5. Model parameters in light condition estimated by multiple linear regression. Coef.: coefficient; $t$-test: Student's $t$-test; $p$ : significance level; DL: duration of contamination in light; ${ }^{*} p<0.05$ (the value usually accepted to retain a coefficient). The final explanatory models are in the form of polynomial multipliers $(-1,+1)$

\begin{tabular}{|c|c|c|c|c|c|c|}
\hline \multirow[b]{2}{*}{ Variables } & \multicolumn{3}{|c|}{ Exponential phase } & \multicolumn{3}{|c|}{ Stationary phase } \\
\hline & Coef. & $t$-test & $p$ & Coef. & $t$-test & $p$ \\
\hline Constant & \multicolumn{3}{|l|}{5.3} & \multicolumn{3}{|l|}{8.6} \\
\hline$[\mathrm{Cd}]$ & 4.9 & 13.90 & $<0.001^{\circ}$ & 8.2 & 10.41 & $<0.001^{\circ}$ \\
\hline [Ca] & -0.7 & 2.01 & $<0.10$ & -3.1 & 3.88 & $<0.01^{\circ}$ \\
\hline DL & 3.5 & 9.97 & $<0.001^{\circ}$ & -4 & 0.05 & $<0.9$ \\
\hline$[\mathrm{Cd}] \cdot[\mathrm{Ca}]$ & -0.7 & 1.93 & $<0.1$ & -3 & 3.81 & $<0.01^{\circ}$ \\
\hline$[C d] \cdot D L$ & 3.4 & 9.83 & $<0.001^{\circ}$ & 5.5 & 0.70 & $<0.5$ \\
\hline \multirow[t]{2}{*}[\mathrm{Ca}]{$\cdot \mathrm{DL}$} & -0.4 & 1.06 & $<0.1$ & -1.9 & 2.36 & $<0.05^{\circ}$ \\
\hline & \multicolumn{3}{|c|}{$\begin{array}{l}\text { Determination coef.: } 0.98 \\
\text { Fisher's F-test: } 74.85 \\
\text { with } 6 \text { and } 9 \mathrm{df} \\
\text { Residual variance: } 1.95\end{array}$} & \multicolumn{3}{|c|}{$\begin{array}{l}\text { Determination coef.: } 0.941 \\
\text { Fisher's F-test: } 23.93 \\
\text { with } 6 \text { and } 9 \text { df } \\
\text { Residual variance: } 9.91\end{array}$} \\
\hline $\begin{array}{l}\text { Final explana- } \\
\text { tory models } \\
\text { ( } Y=\text { ng Cd per } \\
10^{6} \text { cells) }\end{array}$ & \multicolumn{3}{|c|}{$\begin{aligned} Y_{\mathrm{A}}=5.3 & +4.9[\mathrm{Cd}] \\
& +3.5 \mathrm{DL} \\
& +3.4[\mathrm{Cd}] \cdot \mathrm{DL}\end{aligned}$} & \multicolumn{3}{|c|}{$\begin{aligned} Y_{C}=8.6+8.2[\mathrm{Cd}] & -3.1[\mathrm{Ca}] \\
& -3[\mathrm{Cd}] \cdot[\mathrm{Ca}] \\
& -1.9[\mathrm{Ca}] \cdot \mathrm{DL}\end{aligned}$} \\
\hline
\end{tabular}

$1 \mathrm{mMCa}$. This is represented in the model $Y_{C}$ by the negative coefficient of the [Ca] variable. (3) Finally, a given variable does not always have the same effect on the response but is influenced by the values taken by the other variables. For example, when algae in stationary phase were cultivated for only $1 \mathrm{~h}$ in the light in a medium contaminated with $1000 \mu \mathrm{g} \mathrm{Cd} l^{-1}$, the rate of cadmium accumulation was only 1.7 -fold lower in culture medium containing $10 \mathrm{mM} C \mathrm{Ca}$ than in that containing $1 \mathrm{mMCa}$. Thus, the negative effect of the [Ca] varable on the cadmium accumulation decreased with the duration of exposure. This is specified by the negative coefficient of the interaction [Ca].DL.

The presence of interactions ([Cd]·[Ca], [Cd]-DL, $[\mathrm{Cd}] \cdot \mathrm{DD},[\mathrm{Ca}] \cdot \mathrm{DL},[\mathrm{Ca}] \cdot \mathrm{DD}$ in the models clearly 
Table 6. Model parameters in the dark estimated by multiple linear regression. Coef.: coefficient; $t$-test: Student's $t$-test; $p$ : significance level; DD: duration of contamination in the dark; ${ }^{*} p<0.05$ (the value usually accepted to retain a coefficient). The final explanatory models are in the form of polynomial multipliers $(-1,+1)$

\begin{tabular}{|c|c|c|c|c|c|c|}
\hline \multirow[b]{2}{*}{ Variables } & \multicolumn{3}{|c|}{ Exponential phase } & \multicolumn{3}{|c|}{ Stationary phase } \\
\hline & Coef. & $t$-test & $p$ & Coef. & $t$-test & $p$ \\
\hline Constant & 7.2 & & & 7.5 & & \\
\hline$[\mathrm{Cd}]$ & 6 & 17.84 & $<0.001^{\circ}$ & 6.3 & 21.02 & $<0.001^{\circ}$ \\
\hline$[\mathrm{Ca}]$ & -1 & 3.11 & $<0.02^{\circ}$ & -1.1 & 3.67 & $<0.01^{\circ}$ \\
\hline DD & 0.5 & 1.71 & $<0.2$ & 2.8 & 9.17 & $<0.001^{\circ}$ \\
\hline$[\mathrm{Cd}] \cdot[\mathrm{Ca}]$ & -0.9 & 2.64 & $<0.05^{\circ}$ & -1 & 3.22 & $<0.02^{\circ}$ \\
\hline [Cd].DD & 0.4 & 1.17 & $<0.4$ & 3.2 & 10.70 & $<0.001^{\circ}$ \\
\hline \multirow[t]{2}{*}{ [Ca].DD } & -0.8 & 2.31 & $<0.05^{\circ}$ & 0.05 & 0.18 & $<0.9$ \\
\hline & \multicolumn{3}{|c|}{$\begin{array}{l}\text { Determination coef.: } 0.958 \\
\text { Fisher's F-test: } 34.32 \\
\text { with } 6 \text { and } 9 \mathrm{df} \\
\text { Residual variance: } 2.73\end{array}$} & \multicolumn{3}{|c|}{$\begin{array}{l}\text { Determination coef.: } 0.98 \\
\text { Fisher's F-test: } 110.79 \\
\text { with } 6 \text { and } 9 \mathrm{df} \\
\text { Residual variance: } 1.45\end{array}$} \\
\hline $\begin{array}{l}\text { Final explana- } \\
\text { tory models } \\
\text { ( } Y=\text { ng Cd per } \\
10^{6} \text { cells) }\end{array}$ & \multicolumn{3}{|c|}{$\begin{aligned} Y_{\mathrm{B}}=7.2 & +6[\mathrm{Cd}]-1[\mathrm{Ca}] \\
& -0.9[\mathrm{Cd}] \cdot[\mathrm{Ca}] \\
& -0.8[\mathrm{Ca}] \cdot \mathrm{DD}\end{aligned}$} & \multicolumn{3}{|c|}{$\begin{aligned} Y_{\mathrm{D}}=7.5 & +6.3[\mathrm{Cd}]-1.1[\mathrm{Ca}] \\
& +2.8 \mathrm{DD}-1[\mathrm{Cd}] \cdot[\mathrm{Ca}] \\
& +3.2[\mathrm{Cd}] \cdot \mathrm{DD}\end{aligned}$} \\
\hline
\end{tabular}

showed that the factors involved in a complex process must be studied simultaneously.

To visualize these models with their interactions, contour plots of the response surfaces were traced for 2 variables at a time, with all others being at fixed levels. These plots can be easily obtained for each model by calculating the values taken by one factor when the second factor varies (from -1 to +1 ), with the constraint of a given $Y$ value

For each model, only 1 contour plot of the response surface was chosen and these are shown in Figs. 1A, B, C, D.

In Fig. 1A (in the exponential phase and in the light), the contour plots indicate that, whatever the calcium content in the medium, between 1 and $10 \mathrm{mM}$, the greatest cadmium uptake by algae occurred in the highest cadmium concentration, associated with the longest duration of contamination. The effects of these variables are not simply additive.

In Fig. 1B (in the exponential phase and in the dark), we chose the first axis $=[\mathrm{Cd}]$, the second axis $=[\mathrm{Ca}]$ and the fixed variable $=1 \mathrm{~h}$ of exposure time. This figure therefore shows that for short-term contaminations $(1 \mathrm{~h})$, a threshold cadmium concentration with a rather slight effect exists. Below this level, the cadmium accumulation increased with the cadmium and calcium content in the medium. Above this level, the cadmium uptake decreased with the increase in the calcium concentration of the medium.

In Fig. 1C (in the stationary phase and in the light), the calcium concentration was fixed at $10 \mathrm{mM}$. This figure shows that cadmium uptake was inhibited by calcium ions, suggesting an antagonistic role of cal- cium towards cadmium uptake. Moreover, this effect became more pronounced with the exposure time.

In Fig. 1D (in the stationary phase and in the dark),
A

$[\mathrm{Ca}]=1$ or $10 \mathrm{mM}$

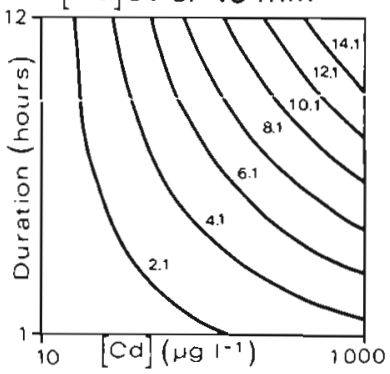

$\mathrm{C}$

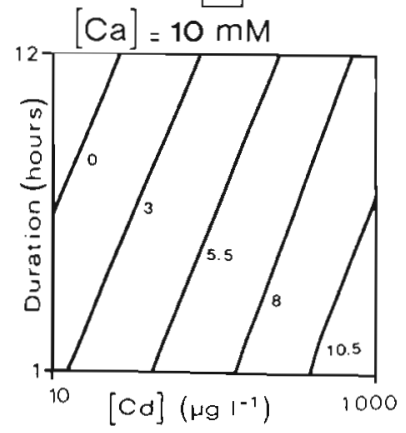

8

Duration $=1 \mathrm{~h}$

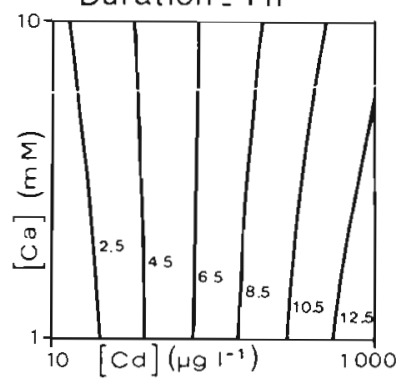

D

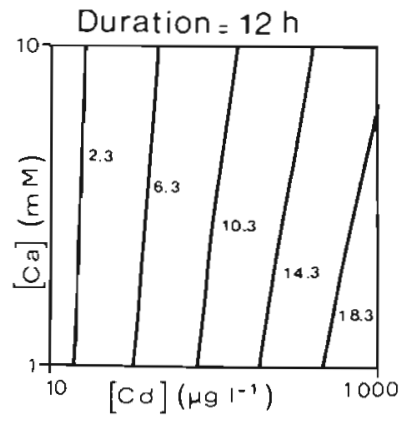

Fig. 1. Contour plots of response surfaces expressed in $\mathrm{ng}$ of accumulated Cd per $10^{6}$ cells in each condition: $(\mathrm{A})$ in exponential phase and in the light; (B) in exponential phase and in the dark; (C) in stationary phase and in the light; (D) in stationary phase and in the dark; and for the following variables: concentration of calcium [Ca], concentration of cadmium [Cd], duration of exposure in the light, DL, and in the dark, DD 
the exposure was $12 \mathrm{~h}$. This figure shows that the greatest cadmium uptake occurred when the medium contained the highest cadmium concentration and the lowest calcium concentration.

\section{DISCUSSION}

In this work, factorial designs have been demonstrated as being useful in assessing the interrelationships between biotic and abiotic factors which are involved in the complex mechanisms of ecotoxicity. The interest of factorial designs lies in the restricted numbers of runs ( 8 runs for a factorial design at 2 levels with 3 factors) and in the description of physiological mechanisms through mathematical interactions.

Obviously, the major factor in the increase in cadmium accumulation by the alga Dunaliella bioculata was the cadmium concentration in the medium, as generally reported for numerous organisms (Fisher et al. 1984, Ravera 1984). However, analysis of models demonstrated that the effect of this factor depended on the exposure time in light or in darkness, on the growth phase and on the calcium concentration.

Thus, in the exponential phase and during the light period or in the stationary phase and during the dark period, the duration variable (D) was a highly significant explanatory variable for the response and interacted with the [Cd] variable. The increase in cadmium uptake by other algae in the exponential phase, cultivated in a $\mathrm{Cd}$-containing medium and during the light period has been also reported (Hart \& Scaife 1977. Gnassia-Barelli $\&$ Hardstedt-Romeo 1982). However, there was a difference between these 2 models, the exponential phase/ light period' and 'stationary phase/dark period' models. While there was no apparent influence of the [Ca] variable in the first model, this variable had a negative effect on the response for the second model. A Ca-Cd antagonism has been also reported for other plants (Fuhrer 1983, Hardiman \& Jacoby 1984) or algae (Singh \& Pandey 1981, Gipps \& Coller 1982). Because $\mathrm{Cd}^{2+}$ and $\mathrm{Ca}^{2+}$ have similar charges and quite similar sizes $\left(\mathrm{Cd}^{2+}: 0.097 \mathrm{~nm}\right.$ and $\left.\mathrm{Ca}^{2+}: 0.099 \mathrm{~nm}\right)$, cadmium may be absorbed by the cells via calcium pathways as calcium channel protein. In non-excitable cells, calcium channels may stay open permanently or may be regulated by cyclic AMP (adenosine monophosphate), which could gradually open and close them (Carafoli \& Penniston 1986). The more probable explanation of the Cd-Ca antagonism may be found in this pathway of the cadmium absorption. The $\mathrm{Cd}^{2+}$ ions would borrow the $\mathrm{Ca}^{2+}$ channels by substituting for $\mathrm{Ca}^{2+}$ ions on the coordination sites within the channels. Therefore, excess of $\mathrm{Ca}^{2+}$ ions would displace $\mathrm{Cd}^{2+}$ ions and would prevent the cadmium uptake.
The negative effect of calcium on cadmium uptake may also be the result of a loss of the membrane's permeability due to the fixation of $\mathrm{Ca}^{2+}$ on the negative sites of the phospholipids of the plasmalemma. Calcium binding sites along the extracellular side of the plasmalemma have also been identified in Physarum polycephalum (Achenbach et al. 1984), and Chara fragilis (Heumann 1983).

However this $[\mathrm{Ca}]$ variable did not seem to explain the low cadmium uptake by the algae in the first model. Other mechanisms must exist to explain this limited cadmium uptake but they cannot be elucidated on account of the selected explanatory variables.

In the 2 other models (exponential phase/dark period and stationary phasenight period), the similar variables and interactions were retained but the coefficients were higher in the case of the stationary phase/light period. In these 2 cases, when the calcium concentration in the medium was high, cadmium uptake decreased when the duration increased. The easiest hypothesis would be that cadmium is expelled from the cells during the exposure. Moreover, for a short duration of exposure when the cadmium concentration is low, the cadmium uptake increased with the calcium concentration. With the aid of the models and of the assessment of the D. [Ca] interaction, we explain these 2 last phenomena by another mechanism involving $\mathrm{Ca}$. From the results obtained by Heuillet et al. (1986), the existence of $\mathrm{Ca}^{2+}$ pumps in Dunaliella bioculata has already been considered and is also supported by the work of Gnassia-Barelli (1987). When the medium is rich in calcium and cadmium, the excess of absorbed $\mathrm{Ca}^{2+}$ ions could activate the $\mathrm{Ca}^{2+}$ pumps in order to maintain a cytosolic calcium homeostasis. In the same way, $\mathrm{Cd}^{2+}$ ions would be expelled from the cell. This could explain the decrease in uptake with time. But for a short duration of contamination and when the medium contained much calcium but not much cadmium, the pumps would preferentially expel $\mathrm{Ca}^{2+}$ ions from the cell. Besides, in a short time, eventual expulsion of $\mathrm{Cd}^{2+}$ ions would have been difficult to quantify.

The mechanisms suggested by this analysis will serve as a basis for further experiments.

Acknowledgements. We thank Messrs M. Vaillant, P. Wirth, D. Rutledge and Feinberg for useful and encouraging discussions. This work was supported by the C.N.R.S., PIREN Sciences de la Vie sector within the framework of an Ecotoxicology A.T.P.

\section{LITERATURE CITED}

Achenbach, F., Achenbach, U., Kessler, D. (1984). Calcium binding sites in plasmodia of Physarum polycephalum as revealed by the pyroantimonate technique. J. Histochem. Cytochem. 32: 1177-1184 
Bard, A. J., Faulkner, L. R. (1980). Electrochemical methods. John Wiley \& Sons, New York

Box, G. E. P., Hunter, W. G., Hunter, J. S. (1978). Statistics for experimenters. John Wiley \& Sons, New York

Break, G. S., Malnes, D., Jensen, A. (1980). Heavy metal tolerance of marine phytoplankton. 4. Combined effect of $\mathrm{Zn}$ and $\mathrm{Cd}$ on growth and uptake in some marine diatoms J. exp. mar. Biol. Ecol. 42: 39-54

Carafoli, E., Penniston, J. T (1986). Le signal calcium. Pour la science 99: 78-90

Cheynier, V., Feinberg, M., Charabas, C., Ducauze, C. (1983). Application of response surface methodology to evaluation of bioconversion experimental conversion. Appl. environ. Microbiol. 45: 643-639

De Fillipis, L. F., Hampp, R., Ziegler, H. (1981). The effects of sublethal concentrations of $\mathrm{Zn}, \mathrm{Cd}, \mathrm{Hg}$ on Euglena. Growth and pigments. Z. Pflanzenphysiol. 101: 37-47

Doelhert, D. H. (1970). Uniform shell designs. Appl. Statist. 19 $231-239$

Dumenil, G., Cremieux, A., Phan-Tan-Luu, R., Combet, M (1975). Bioconversion from DL-homoserine to L-threonine. I. Application of factorial designs. Eur. J. appl. Microbiol. 1. 213-220

Feinberg, M., Wirth, P. (1984). Aperçu des méthodes d'optimisation en chimie analytique. Analysis 12: 490-495

Fisher, N. S., Bohe, M., Teyssié, J. L. (1984). Accumulation and toxicity of $\mathrm{Cd}, \mathrm{Zn}, \mathrm{Ag}$ and $\mathrm{Hg}$ in four marine phytoplankton. Mar. Ecol. Prog. Ser. 18: 201-213

Flateau, G. N., Gauthier, M. J. (1983). Accumulation du Cd par Mytilus edulis en présence de souches bactériennes sensibles ou résistantes à ce métal. Can. J. Microbiol. 29: 210-217

Fuhrer, J. (1983). Phytotoxic effects of cadmium in leaf segments of Avena sativa L., and the protective role of calcium. Experientia 39: 525-526

Gipps, J. F., Coller, B. A. W. (1982). Effect of some nutrient cations on uptake of cadmium by Chlorella pyrenoidosa. Aust. I. mar. Freshwat. Res. 33.979-987

Gnassia-Barelli, M., Härdstedt-Roméo, M. (1982). Short-term time series of $\mathrm{Cu}$ and $\mathrm{Cd}$ uptake by Cricosphaera elongata (Droop) Braarud. J. exp. mar. Biol. Ecol. 61. 287-298

Gnassia-Barelli, M., Roméo, M., Puiseux-Dao, S. (1987). Effets de différents inhibiteurs sur l'accumulation de zinc et du cadmium par l'algue phytoplanctonique Hymenomonas elongata en culture. Proc. Symp. Int. 'Impacts Cellulaires en Ecotoxicologie', Lyon (in press)

Gray, J. S. (1974). Synergic effects of three heavy metals on growth rate of marine ciliate protozoans. In: Vernberg, $\mathrm{F}$. J., Vernberg, W. B. (eds.) Pollution and physiology of marine organisms. Academic Press, New York, p. 465-485

Grizeau, D., Calvayrac, R., Puiseux-Dao, S. (1982). Action de l'EPTC et de certains de ses antagonistes sur la croissance des cultures de Dunaliella bioculata. C. r. hebd. Séanc. Acad. Sci., Paris 294 (Série III): 353-356

Hardiman, R, T., Jacoby, B. (1984). Absorption and translocation of cadmium in bush beans (Phaseolus vulgaris). Physiol. plant. 61: 670-674

Härstedt-Roméo, M., Gnassia-Barelli, M. (1980). Effect of complexation by natural phytoplankton exudates on the accumulation of cadmium and copper by the haptophyceae Cricosphaera elongata. Mar. Biol. 59: 79-84
Hart, B. A., Scaife, B. D. (1977). Toxicity and bioaccumulation of cadmium in Chlorella pyrenoidosa. Environ. Res. 14 $401-413$

Heuillet, E., Moreau, A., Halpern, S., Jeanne, N., PuiseuxDao, S. (1986). Cadmium-binding to a thiol-molecule in vacuoles of Dunaliella bioculata contaminated with $\mathrm{CdCl}_{2}$ electron probe microanalysis. Biol. Cell 58: 79-86

Heumann, H. G. (1983). $\mathrm{Ca}^{2+}$-dependent deposits at the plasmalemma of Chara internodal cells. Histochemistry 79 $69-75$

Jeanne, N. (1982). Recherche sur les effets de quelques polluants au niveau cellulaire. Exploitation d'un modèle: le Dunaliella bioculata. Thèse d'Etat, Université Paris VII

Jenkins, K. D., Sanders, B. M., Sunda, W. G. (1983). Metal regulation and toxicity in aquatic organisms. In: Singer, $T$ P., Mansour, T. E., Ondarza, R. N. (eds.) Symposium on the biochemical basis of drug action. Academic Press, Orlando, p. 277-287

Macleese, D. W., Ray, S. A. (1984). Uptake and excretion of $\mathrm{Cd}, \mathrm{Cd}-\mathrm{EDTA}$ and $\mathrm{Zn}$ by Macoma baltica. Bull. environ. Contam. Toxicol. 32: 85-92

Marano, F. (1980). Synchronisation et cycle cellulaire du Dunaliella bioculata. Utilisation de ce modèle expérimental pour l'étude du mode d'action de l'acroléine. Thèse d'Etat, Université Paris VII

Matthews, R. J., Scott, R. G., Morgan, S. L. (1981). Characterization of an enzymic determination of arsenic (v) based on response surface methodology. Analytica chim. Acta 133: $169-182$

Overnell, J. (1975). The effect of heavy metals on photosynthesis and loss of cell $\mathrm{K}^{+}$in two species of marine algae Dunaliella bioculata and Phaedactylum tricornutum. Mar. Biol. 29: 99-103

Plishker, G. A. (1984). Effects of cadmium and zinc on calcium uptake in human red blood cells. Am. J. Physiol. 247: 143-149

Rãvera, O. (1984). Ca in freshwater ecosystems. Experientia 40: $1-13$

Ray, S. (1984). Bioaccumulation of $\mathrm{Cd}$ in marine organisms. Experientia 40: 14-22

Rebhun, S., Ben-Amotz, A. (1986). Effect of $\mathrm{NaCl}$ concentration on cadmium uptake by the halophylic alga Dunaliella salina. Mar. Ecol. Prog. Ser. 30: 215-219

Sanderson, I. M., Kennerley, J. W., Parr, G. D. (1984). An evaluation of the relative importance of formulation and process variables using factorial design. J. Pharm. Pharmacol. 36: 789-795

Santiago-Fandino, V J.R. (1983). The effects of nickel and cadmium on the growth rate of Hydra littoralis and on assessment of the rate of uptake of ${ }^{63} \mathrm{Ni}$ and ${ }^{14} \mathrm{C}$ by the same organism. Wat. Res. 17: 917-923

Singh, S. P., Pandey, A. K. (1981). Heavy metal interactions studies with a blue green alga. Acta Bot. Indica 9: 290-296

Stary, J., Kratzer, K. (1982). The cumulation of toxic metals on algae. J. environ. analyt. Chem. 12: 65-71

Stevens, C. F. (1984). Biophysical studies on ion channels. Science 225: $1346-1350$

Sylverberg, B. A. (1976). Cd-induced ultrastructural changes in mitochondria of freshwater green alga. Phycologia 15 : 155-159 